\title{
Purification and Characterization of Cytochrome P450 2E2 from Hepatic Microsomes of Neonatal Rabbits ${ }^{1}$
}

\author{
Xinxin Ding, Steven J. Pernecky, and Minor J. Coon ${ }^{2}$ \\ Department of Biological Chemistry, Medical School, The University of Michigan, Ann Arbor, Michigan 48109-0606
}

Received June 27, 1991, and in revised form August 14, 1991

The alcohol-inducible P450 2E subfamily in the rabbit has two known members that differ in only 16 amino acid residues scattered throughout the polypeptide chain. P450 2E1 has been thoroughly characterized, and is known to have diverse inducers and substrates. Little is known, however, about the properties of $\mathrm{P450} 2 \mathrm{E2}$, since efforts to isolate this isozyme from adult rabbits have been unsuccessful. In the present study, $2 \mathrm{E} 2$ was purified to electrophoretic homogeneity from liver microsomes of neonatal rabbits with the use of 4-methylpyrazole as a stabilizing agent. The purified cytochrome was identified as $2 \mathrm{E2}$ by $\mathrm{NH}_{2}$-terminal amino acid sequence analysis as well as by immunoblot analysis with three different antibodies to 2E1. Purified 2E2, in contrast to 2E1, is predominantly low-spin in the presence of $20 \%$ glycerol, but is in a mixed high- and low-spin state as the concentration of glycerol is decreased. The catalytic properties of purified $2 E 1$ and $2 E 2$ were compared in the reconstituted system with a variety of substrates, including alcohols, ethers, nitrosamines, and aromatic compounds. Differences between the two enzymes in catalytic activity and in the interaction with cytochrome $b_{5}$ were observed with some but not all of the substrates tested. Purified $2 E 1$ and $2 E 2$ both consume molecular oxygen relatively rapidly during NADPH oxidation in the absence of an added substrate, and stoichiometric determinations indicated that only about $20 \%$ of the $\mathrm{O}_{2}$ was reduced to $\mathrm{H}_{2} \mathrm{O}_{2}$, with the remainder apparently undergoing four-electron reduction to water. (c) 1991 Academic Press, Inc.

Chronic ethanol consumption by animals and humans has been linked by epidemiological evidence to cancer, chemical toxicities, and other pathological states, with increasing attention being paid in recent years to the role

\footnotetext{
${ }^{1}$ This investigation was supported by Grant AA-06221 from the National Institute on Alcohol Abuse and Alcoholism.

${ }^{2}$ To whom correspondence should be addressed at Department of Biological Chemistry, Medical School, The University of Michigan, 1301 Catherine Road, Ann Arbor, MI 48109-0606. Fax: (313) 763-4581.
}

of alcohol-inducible cytochrome $\mathrm{P} 450$ (1). In the rabbit, the P450 2E subfamily [see Ref. (2) for recommended nomenclature] has two known members, $2 \mathrm{E} 1^{3}$ and $2 \mathrm{E} 2$ (3), which differ in only 16 amino acid residues scattered throughout the polypeptide chain. 2E1 (initially called P450 3a), which was originally purified from liver microsomes of ethanol-treated rabbits in this laboratory (4), has relatively high activity in the oxidation of ethanol and other alcohols (5) as well as of many other compounds of pharmacological and toxicological concern, including nitrosamines, alkanes, halogenated alkanes, ethers, and aromatic compounds $(1,6)$. This isozyme is also active toward compounds of physiological importance, such as lipid hydroperoxides (7) and acetone (8). Furthermore, purified $2 \mathrm{E} 1$ is unusual in that it rapidly consumes $\mathrm{O}_{2}$ and NADPH in the absence of a substrate (9); the activated oxygen species generated by $2 \mathrm{E} 1$ have been implicated in pathological processes that may result in tissue damage $(10,11)$.

Evidence for $2 \mathrm{E} 2$ was first obtained by isolation of the gene (3), and subsequent studies showed that 2E2 mRNA in adult rabbit liver is present at half the level of the 2E1 transcript (12). Little is known, however, about the catalytic properties of $2 \mathrm{E} 2$ since earlier attempts in our laboratory to isolate the $2 \mathrm{E} 2$ protein were unsuccessful. However, a $2 \mathrm{E} 2 \mathrm{cDNA}$ was recently isolated from a rabbit liver cDNA library and expressed in Saccharomyces cerevisiae (13). The expressed microsomal $2 \mathrm{E} 2$ was found to be active toward $N, N$-diethylnitrosamine and butanol, but the cytochrome was converted to inactive P420 under conditions routinely used for the isolation of $2 \mathrm{E} 1$ from adult rabbits. Interestingly, the inactivation was prevented in the presence of 4-MP, a compound known to bind to rabbit $2 \mathrm{E} 1$ with particularly high affinity (14).

Recently, Bonfils et al. (15) identified a P450 in neonatal rabbit liver (called P450 2y) that was related to, but dis-

\footnotetext{
${ }^{3}$ Abbreviations used: $2 \mathrm{E} 1$ and 2E2, P450 cytochromes 2E1 and 2E2, respectively; SDS-PAGE, sodium dodecyl sulfate-polyacrylamide gel electrophoresis; PEG, polyethylene glycol; 4-MP, 4-methylpyrazole; $b_{5}$, cytochrome $b_{5}$; NP-10, Tergitol NP-10.
} 
tinct from, $2 \mathrm{E} 1 . \mathrm{NH}_{2}$-terminal sequence analysis and immunological cross-reaction with anti-2E1 antibody indicated that this neonatal cytochrome was probably $2 \mathrm{E} 2$. Their important finding that P450 2y, but not 2E1, was abundant in the hepatic microsomes of 1- to 3-week-old rabbits (15) is in accord with our recent observation that 2E2 mRNA is detectable in rabbit liver immediately after birth whereas 2E1 mRNA is not found until Day 14 (16). The purification of P450 2y from neonatal hepatic microsomes resulted in a preparation of low specific content due, in part, to the presence of a significant amount of $P 420$, and information on the catalytic properties of the partially purified P450 2y was not reported (15).

In the present study, 2E2 was purified from the liver of 2-week-old rabbits to a content of $15.9 \mathrm{nmol}$ of heme/ mg of protein with 4-MP present to stabilize the cytochrome during purification, and in other experiments it was copurified with $2 \mathrm{E} 1$ from liver microsomes of acetonetreated adult rabbits. We now report the unique spectral properties of $2 \mathrm{E} 2$ as well as its catalytic activities, in comparison with those of $2 \mathrm{E} 1$, toward a number of substrates in a reconstituted system.

\section{MATERIALS AND METHODS}

Animals and microsomes. Two-week-old male New Zealand White rabbits obtained from a local supplier were sacrificed upon arrival. Adult $(2.5-\mathrm{kg})$ male rabbits were treated with $1 \%$ acetone in the drinking water for 7 days and allowed free access to Purina rabbit chow. Pooled livers from 20 neonates (approximately $8 \mathrm{~g} / \mathrm{rabbit}$ ) or from 9 acetone-treated adult animals (about $70 \mathrm{~g} / \mathrm{rabbit}$ ) were homogenized, and pyrophosphatewashed microsomes were prepared from the two groups according to the procedure described previously (17) except that $0.05 \mathrm{mM}$ 4-MP was included in all buffers.

Purification of 2E2 from hepatic microsomes of neonatal rabbits. The following protocol is based, with major modification, on the procedure described for the purification of $2 \mathrm{E} 1$ from ethanol-treated rabbits (4, 18). Unless otherwise indicated, all buffers contained $0.05 \mathrm{mM}$ 4-MP and $20 \%$ glycerol $(\mathrm{v} / \mathrm{v})$. Phosphate buffers were prepared as the potassium salt; the fractionation procedures and $\mathrm{pH}$ measurements were conducted at $4^{\circ} \mathrm{C}$.

In a typical procedure, micrusumes from 16 rabbits were suspended in $0.1 \mathrm{M}$ Tris-acetate buffer, $\mathrm{pH} 7.4$, containing $0.1 \mathrm{M} \mathrm{KCl}$ and $1 \mathrm{mM}$ EDTA, at a protein concentration of $1.6 \mathrm{mg} / \mathrm{ml}$. NP-10 and sodium cholate were then added as $10 \%(\mathrm{w} / \mathrm{v})$ solutions to final concentrations of $1 \%$ each. The mixture was stirred for $2 \mathrm{~h}$ and fractionated with PEG 8000 as described earlier (17). The 7 to $14 \%$ PEG supernatant fraction was combined with $2 \mathrm{vol}$ of $10 \%$ glycerol $(\mathrm{v} / \mathrm{v})$ and applied to a BioRad HTP column $(2.5 \times 20 \mathrm{~cm})$ previously equilibrated with $5 \mathrm{mM}$ phosphate buffer, $\mathrm{pH} 7.4$, containing $0.2 \% \mathrm{NP}-10$ (buffer A). The column was washed with 5 vol of buffer $A$ at $10 \mathrm{mM}$ phosphate, and eluted with a 200-ml linear gradient from 10 to $70 \mathrm{mM}$ phosphate in buffer $A$ and an additional $250 \mathrm{ml}$ of $70 \mathrm{mM}$ phosphate in buffer $A$. Fractions eluting at $70 \mathrm{mM}$ phosphate that contained $2 \mathrm{E} 2$, as judged by SDS-PAGE, were pooled and concentrated to about $50 \mathrm{ml}$ by ultrafiltration with an Amicon PM-30 membrane, dialyzed overnight against two changes (1 liter each) of $3 \mathrm{mM}$ phosphate buffer, $\mathrm{pH} 7.7$, containing $0.6 \% \mathrm{NP}-10$ and $0.1 \mathrm{mM}$ EDTA (buffer B), diluted with 2 vol of buffer B, and applied to a DEAESepharose (Pharmacia) column $(1 \times 20 \mathrm{~cm})$ previously equilibrated with buffer $B$. The column was washed sequentially with 3 vol of buffer $B$ and 5 vol of buffer $B$ at $20 \mathrm{mM}$ phosphate, and $2 \mathrm{E} 2$ was eluted with 10 vol of buffer B at $50 \mathrm{mM}$ phosphate. Samples of column eluate were analyzed by SDS-PAGE, and the fractions with $2 \mathrm{E} 2$ as the predominant protein were combined. The pooled fractions, which had a maximal absorbance at $415 \mathrm{~nm}$ and contained $b_{5}$ and P450 2C3 (form 3b) in addition to $2 \mathrm{E} 2$, were concentrated to less than $40 \mathrm{ml}$ by ultrafiltration, dialyzed against two changes (1 liter each) of $10 \mathrm{mM}$ phosphate buffer. pH 6.4, containing $0.5 \%$ NP-10 and $1 \mathrm{mM}$ EDTA (buffer C) for $36 \mathrm{~h}$, and applied to an S-Sepharose column $(1 \times 20 \mathrm{~cm})$ previously equilibrated with buffer $\mathrm{C}$. The S-Sepharose column was treated sequentially with $5 \mathrm{vol}$ of buffer $C$ (to remove $b_{5}$ ) and a linear gradient ( $15 \mathrm{vol}$ ) of 10 to $200 \mathrm{mM}$ phosphate, pH 6.4, in buffer C. P450 $2 \mathrm{C} 3$ (maximal absorbance at $417 \mathrm{~nm}$ ) was eluted at approximately $75 \mathrm{mM}$ phosphate, and 2E2 (with an absorbance maximum at about $422 \mathrm{~nm}$ because of 4-MP binding) was eluted in the second half of the gradient and in fractions abtained after further treatment of the column with $200 \mathrm{mM}$ phosphate in buffer C. The pooled $2 \mathrm{E} 2$-rich fractions, to which $1 / 10 \mathrm{vol}$ of $1 \mathrm{M} \mathrm{K}_{2} \mathrm{HPO}_{4}$ was added to raise the $\mathrm{pH}$, were then dialyzed for $24 \mathrm{~h}$ against three changes

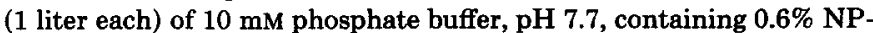
10 and $0.1 \mathrm{mM}$ EDTA (buffer D), and then, after dilution (1:1) with a solution containing $0.6 \% \mathrm{NP}-10$ and $20 \%$ glycerol, were applied to a second DEAE-Sepharose column $(0.7 \times 25 \mathrm{~cm})$ previously equilibrated with buffer $\mathrm{D}$. The nonbound fraction and fractions obtained by washing this column with buffer D (10 to $15 \mathrm{vol}$ ) had an absorbance maximum at about $424 \mathrm{~nm}$ and exhibited a single major band upon SDS-PAGE analysis. These fractions were pooled and, after 1:1 dilution with $5 \mathrm{mM}$ phosphate buffer, pH 7.4 (buffer E), were applied to a second HTP column $(0.7 \times 6 \mathrm{~cm})$ previously equilibrated with buffer $E$. The column was washed sequentially with 5 vol each of $10 \mathrm{mM}$ phosphate, $30 \mathrm{mM}$ phosphate, and $45 \mathrm{mM}$ phosphate buffer, $\mathrm{pH} 7.4$, containing $0.2 \% \mathrm{NP}$ 10 , and then with a sufficient amount of $10 \mathrm{mM}$ phosphate in buffer $E$ so that the absorbance of the eluate at $276 \mathrm{~nm}$ was less than 0.01 . The column was then washed with $3 \mathrm{vol}$ of $10 \mathrm{mM}$ phosphate buffer, $\mathrm{pH} 7.4$, without 4-MP, and the enzyme was eluted with $500 \mathrm{mM}$ phosphate buffer, $\mathrm{pH} 7.4$, containing $0.1 \%$ sodium cholate (without 4-MP). The preparation was dialyzed against four changes (100 vol each) of $100 \mathrm{mM}$ phosphate buffer containing $5 \%$ glycerol and $0.1 \mathrm{mM}$ EDTA for $24 \mathrm{~h}$ to remove cholate and residual 4-MP. The final preparation of $2 \mathrm{E} 2$, which was electrophoretically homogeneous and had a content of $15.9 \mathrm{nmol}$ of heme/ mg of protein, was stable for at least 2 months when stored at $-20^{\circ} \mathrm{C}$.

Purification of $2 E 1$ and $2 E 2$ from hepatic microsomes of acetone-treated adult rabbits. Cytochromes $2 \mathrm{E} 1$ and $2 \mathrm{E} 2$ were copurified from adult liver microsomes in the presence of 4-MP according to essentially the same procedure as described above for the purification of neonatal $2 \mathrm{E} 2$, except that the fraction precipitating from 7 to $14 \%$ PEG was used and the first HTP column was omitted. The PEG fraction was dialyzed overnight against $200 \mathrm{vol}$ of buffer $\mathrm{B}$ and applied to the first DEAESepharose column. The final preparations showed a single band upon SDS-PAGE and had contents of about $18 \mathrm{nmol}$ of heme/mg protein.

Stoichiometric analyses. Stoichiometric determinations were conducted at $30^{\circ} \mathrm{C}$ under end-point conditions as described by Gorsky et al. (9) except that reaction mixtures contained $0.3 \mu \mathrm{M} 2 \mathrm{E} 1$ or $2 \mathrm{E} 2,0.3$ $\mu \mathrm{M}$ NADPH-cytochrome $\mathrm{P} 450$ reductase, and $30 \mu \mathrm{g} / \mathrm{ml}$ dilauroylglyceryl3-phosphorylcholine in $100 \mathrm{mM}$ potassium phosphate buffer, $\mathrm{pH} 7.4$. NADPH (150 nmol per milliliter, final concentration) was added to initiate oxygen consumption, which was measured with a Clark-type electrode in conjunction with a Yellow Springs Instrument 35 monitor. The extent of NADPH oxidation was ascertained from the absorbance of the reaction mixture at $340 \mathrm{~nm}$ following cessation of oxygen consumption. Aliquots were then removed for measurement of $\mathrm{H}_{2} \mathrm{O}_{2}$ by the ferrithiocyanate method (19). The initial oxygen concentration was 241 $\mu \mathrm{M}$ as determined by the phenazine methosulfate/NADH reaction (20), and $\mathrm{H}_{2} \mathrm{O}_{2}$ standard solutions were calibrated by potassium permanganate titration (21).

Monooxygenase assays. The composition of individual reaction mixtures is given in the table legends. All reactions were initiated by the addition of NADPH and carried out at $37^{\circ} \mathrm{C}$ for lengths of time that represented the initial linear rate of product formation. For reactions in which $b_{5}$ was included, the cytochrome was added to the reaction mixture after the addition of the reconstituted P450 system, as described previously (22). 'The rates of product formation are the average of duplicate or triplicate incubations corrected for zero-time blanks that were 
quenched prior to the addition of NADPH. The hydroxylation of $p$ nitrophenol to 4-nitrocatechol was determined as described by Koop (23). The formaldehyde formed from the $\mathrm{N}$-demethylation of $\mathrm{N}$-nitrosodimethylamine, $N$-nitroso- $N$-methyl- $N$-phenylamine, and hexamethylphosphoramide, and the $\mathrm{O}$-demethylation of anisole and ethylene glycol dimethyl ether, was measured by the method of Nash (24). The formation of acetaldehyde from ethanol and $N$-nitrosodiethylamine and the formation of butyraldehyde from butanol were determined by gas chromatography of the headspace gas of the reaction mixture as described previously $(25,26)$. The hydroxylation of aniline to $p$-aminophenol was assayed colorimetrically (27).

Other methods and materials. The concentration of P450 in microsomal suspensions and in crude fractions was determined from the $\mathrm{CO}$ difference spectrum of the reduced cytochrome (28). Heme was determined as the reduced pyridine hemochrome (29). The optical spectra of purified $2 \mathrm{E} 1$ and $2 \mathrm{E} 2$ were determined at $23-25^{\circ} \mathrm{C}$ with a Cary 219 spectrophotometer. $\mathrm{NH}_{2}$-terminal amino acid sequences were determined by Edman degradation with an Applied Biosystems Model 470A gasphase protein sequencer $(30)$ at the University of Michigan Protein Sequencing Facility. SDS-PAGE and immunoblot analyses were carried out as previously described (31). Protein was measured routinely by the method of Lowry et al. (32) with bovine serum albumin as a standard. The protein content of purified $2 \mathrm{E} 1$ and $2 \mathrm{E} 2$ was determined by amino acid analysis (33), which gave values $16 \%$ less than the Lowry method. The method of Strittmatter et al. (34) was used for the purification of

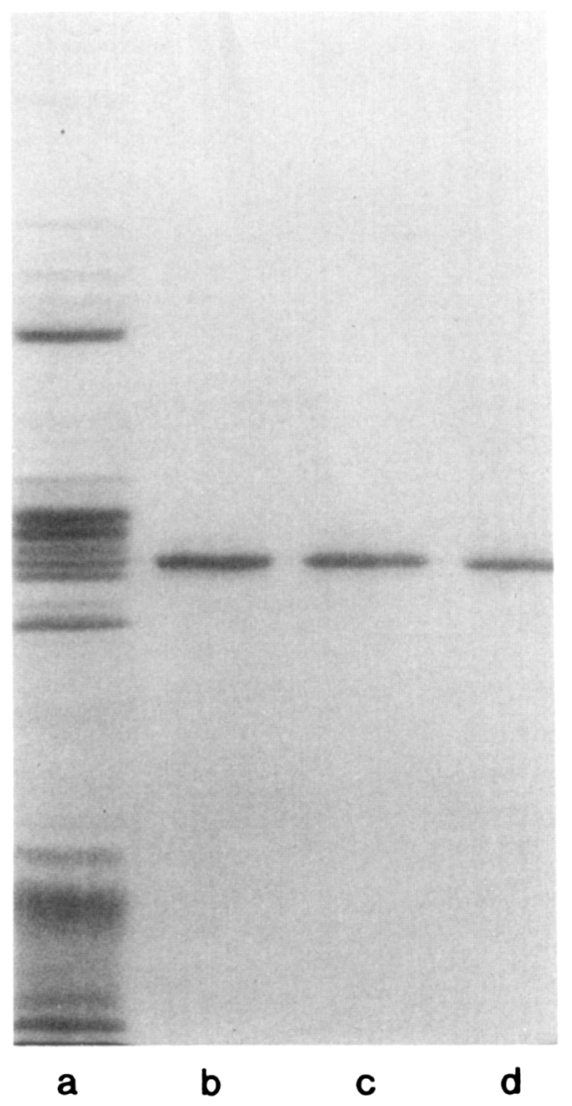

FIG. 1. SDS-PAGE of microsomes and purified $\mathbf{P 4 5 0}$ preparations. Protein samples were applied to a $7.5 \%$ polyacrylamide gel. Migration was from top to bottom, and visualization was by silver staining. Lane a, hepatic microsomal proteins from 2-week-old rabbits, $1.7 \mu \mathrm{g}$ of protein; lanes $b$ and d, purified 2E2 from neonatal rabbits and purified $2 \mathrm{E} 1$ from adult rabbits, respectively, $0.1 \mu \mathrm{g}$ of protein; and lane c, a 1:1 mixture of purified $2 \mathrm{E} 1$ and purified $2 \mathrm{E} 2,0.1 \mu \mathrm{g}$ of total protein.
TABLE I

Purification of 2E2 from Hepatic Microsomes of Neonatal Rabbits

\begin{tabular}{lccc}
\hline \multicolumn{1}{c}{ Preparation } & $\begin{array}{c}\text { Protein } \\
(\mathbf{m g})\end{array}$ & $\begin{array}{c}\text { P450 content }^{a} \\
\text { (nmol/mg protein) }\end{array}$ & $\begin{array}{c}\text { Yield } \\
(\%)\end{array}$ \\
\hline $\begin{array}{l}\text { Pyrophosphate-treated } \\
\text { microsomes }\end{array}$ & 1100 & 0.7 & 100 \\
$\begin{array}{l}\text { Polyethylene glycol (14\%) } \\
\text { supernatant fraction }\end{array}$ & 471 & 1.1 & 67 \\
$\begin{array}{l}\text { First HTP column eluate } \\
\text { First DEAE-Sepharose }\end{array}$ & 142 & 1.2 & 22 \\
$\quad$ column eluate & 21.4 & 3.3 & 9.2 \\
$\begin{array}{l}\text { S-Sepharose column eluate } \\
\text { Second DEAE-Sepharose }\end{array}$ & 4.5 & 9.1 & 5.3 \\
$\quad$ column eluate & 2.6 & 11.4 & 3.8 \\
Second HTP column eluate & 1.3 & 15.9 & 2.7 \\
\hline
\end{tabular}

a The P450 concentration for the purified 2E2 is based on the heme content; all other values are based on the determination of P450 as the CO complex. Typical results are presented.

$b_{5}$ from rabbit liver microsomes. The electrophoretically homogeneous preparations had specific contents of 40 to $50 \mathrm{nmol}$ of $b_{5} / \mathrm{mg}$ of protein. NADPH-cytochrome P-450 reductase was purified from microsomes obtained from phenobarbital-treated rabbits (35) and had a specific activity of 45 to $60 \mu \mathrm{mol}$ of cytochrome $c$ reduced per minute per milligram of protein. The preparation and characterization of polyclonal (25) and monoclonal (31) antibodies to rabbit $2 \mathrm{E} 1$ have been described. Monoclonal antibody (1-98-1) to rat 2E1 (36) was a gift from Dr. Harry V. Gelboin, National Cancer Institute, NIH; 4-MP was obtained from Sigma; cholic acid, from Aldrich, was recrystallized from $95 \%$ ethanol. Other materials were obtained as described previously $(4,25,31,37)$.

\section{RESULTS AND DISCUSSION}

Purification of 2E2. Several bands were observed in the molecular weight range expected for $P 450$ enzymes (Fig. 1) when hepatic microsomes from 2-week-old rabbits were submitted to SDS-PAGE. In addition to $2 \mathrm{E} 2$, at least five other $\mathrm{P} 450$ forms have been identified in the liver of neonatal rabbits, including $1 \mathrm{~A} 1,1 \mathrm{~A} 2,2 \mathrm{~B} 4,2 \mathrm{C} 3$, and $3 \mathrm{~A} 6$ (15). The purification of $2 \mathrm{E} 2$ from neonatal liver microsomes to electrophoretic homogeneity (Fig. 1) is summarized in Table $\mathrm{I}$. The liver of 2 -week-old rabbits has a much lower content of total microsomal protein than that of adult liver ( $8 \mathrm{vs} 50 \mathrm{mg} / \mathrm{g}$ of tissue) and a lower specific content of total microsomal P450, but has a relatively high content of lipids. To achieve optimal solubilization, it was necessary to dilute the microsomal preparation to a final concentration of less than $1.5 \mathrm{mg}$ of protein $/ \mathrm{ml}$ with NP-10 and cholate present at $1 \%$ each. Perhaps as a result of the high fat content and the stringent solubilization conditions, most of the solubilized microsomal P450 failed to precipitate with 14\% PEG. The fraction precipitating with 7 to $14 \%$ PEG had about $30 \%$ of the total starting microsomal P450, but was not suitable for further processing because it could not be resolubilized. In the typical experiment shown, the overall yield based on starting total P450 was $2.7 \%$. The final preparation of 
1

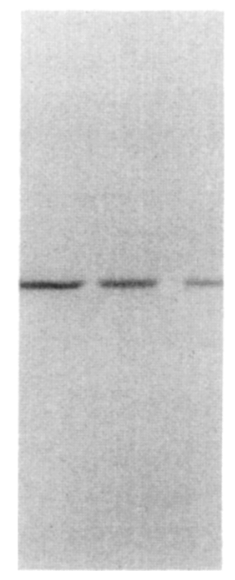

2

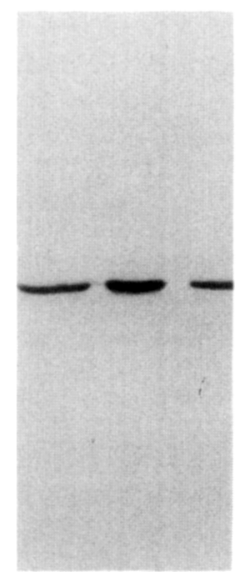

3

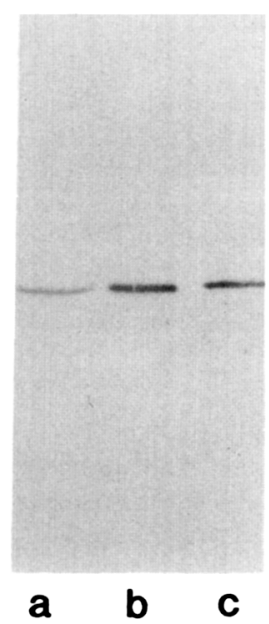

FIG. 2. Immunoblot analysis of microsomes and purified P450 preparations. Protein samples were submitted to electrophoresis in $7.5 \%$ acrylamide gels and electrophoretically transferred to nitrocellulose sheets. For immunochemical detection of $2 \mathrm{E}$ protein, the nitrocellulose sheets were treated with polyclonal (experiment 1) or monoclonal antibodies to rabbit $2 \mathrm{E} 1$ (experiment 2), or with a monoclonal antibody (1-98-1) to rat 2E1 (experiment 3). Lane a, hepatic microsomal proteins from 2-week-old rabbits, $5 \mu \mathrm{g}$ of protein; and lanes $\mathrm{b}$ and c, purified $2 \mathrm{E} 2$ and $2 \mathrm{E} 1$, respectively, $0.1 \mu \mathrm{g}$ of protein.

2E2 had a content of $15.9 \mathrm{nmol}$ of heme per milligram of protein and comigrated with purified 2E1 on SDS-PAGE (Fig. 1).

In other experiments, a mixture of $2 \mathrm{E} 1$ and $2 \mathrm{E} 2$ was purified from liver microsomes of acetone-treated adult rabbits in the presence of 4-MP. When the same purification procedure was carried out in the absence of 4-MP, however, only $2 \mathrm{E} 1$ was obtained in the final preparation. Thus, stabilization with 4-MP leads to the retention of $2 \mathrm{E} 2$ in the final preparation from adult animals, but attempts to separate the two proteins have so far been unsuccessful.

$\mathrm{NH}_{2}$-terminal sequence analysis. Cytochrome $2 \mathrm{E} 2$ is distinguished from $2 \mathrm{E} 1$ by the amino acid at position 14 of the $\mathrm{NH}_{2}$-terminus, which is Ala in $2 \mathrm{E} 2$ and Val in $2 \mathrm{E} 1$ (3). The first 26 amino acid residues in the $\mathrm{NH}_{2}$-terminus of the purified neonatal $2 \mathrm{E} 2$ were determined and found to agree with those deduced from the genomic sequence of $2 \mathrm{E} 2$ (3), with Ala at position 14 and only a trace of Val that was barely above background. The predicted $\mathrm{NH}_{2}$ terminal Met was not present in the 2E2 protein, nor was it found in the $2 \mathrm{E} 1$ protein (4). The first three residues in the $\mathrm{NH}_{2}$-terminus (Ala-Val-Leu) were absent in approximately $30 \%$ of the purified $2 \mathrm{E} 2$ preparation, whereas $50 \%$ of the $\mathrm{P} 4502 \mathrm{y}$ preparation did not possess these three amino acid residues (15). The lower amount of degraded protein and the absence of $\mathrm{P} 420$ in the highly purified preparation of $2 \mathrm{E} 2$ reported in the present study suggest that 4-MP not only prevents the conversion of 2E2 to P420, but also protects the enzyme to some extent from proteolytic degradation. The importance of these three residues to the activity as well as stability of the cytochrome remains to be determined, but a recent study from this laboratory has shown that removal of the $\mathrm{NH}_{2}-$ terminal 29 residues of $2 \mathrm{E} 1$ did not affect its activity toward ethanol or $N, N$-nitrosodiethylamine (38).
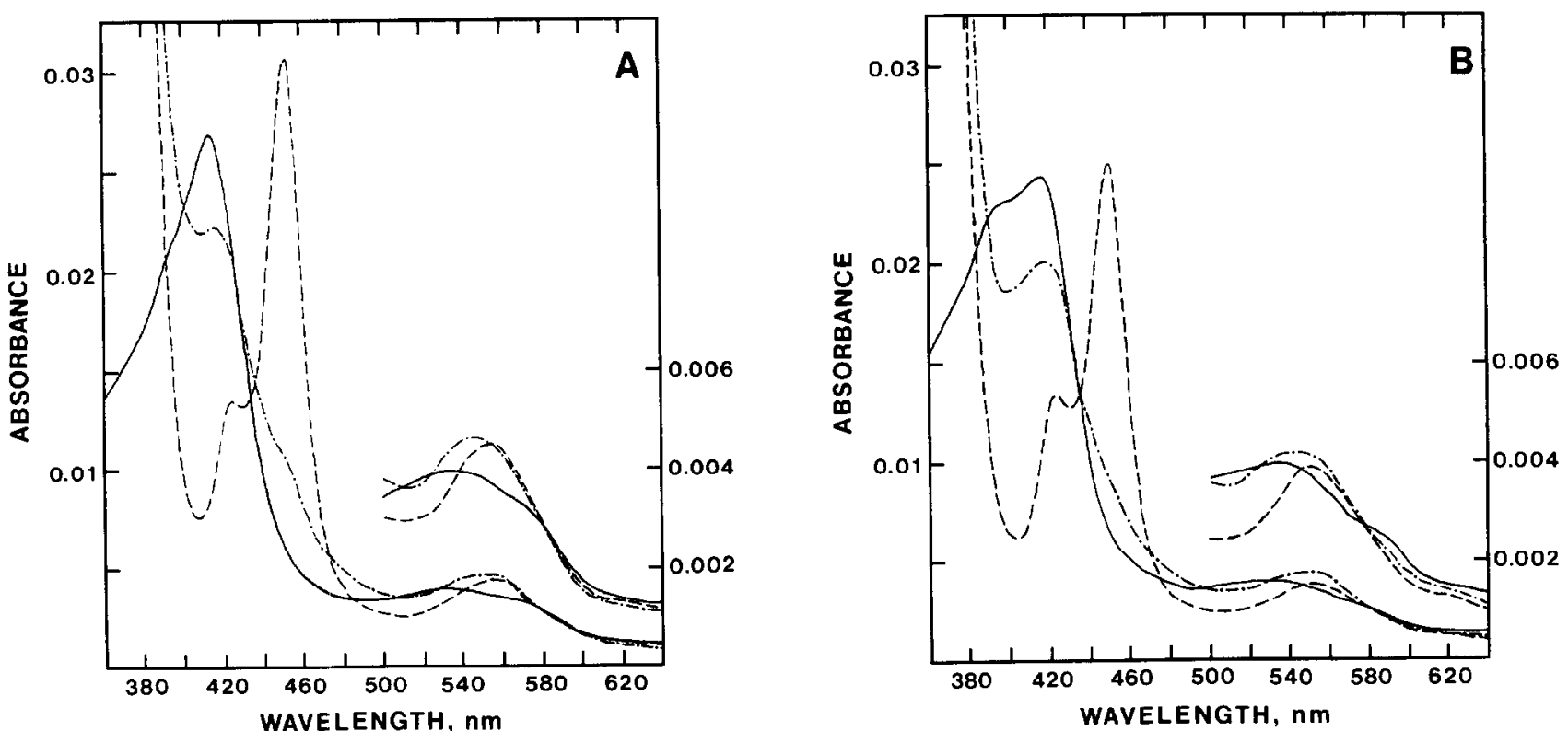

FIG. 3. Absolute spectra of purified $2 \mathrm{E} 2$ from neonatal rabbits. The concentration of $2 \mathrm{E} 2$, based on heme analysis, was $0.25 \mathrm{nmol}$ per milliliter of $0.1 \mathrm{M}$ potassium phosphate buffer, $\mathrm{pH} 7.4$, containing $20 \%$ (A) or $0.13 \%$ glycerol (B). (-) Oxidized, (---) dithionite-reduced, (---) reduced-CO complex. 


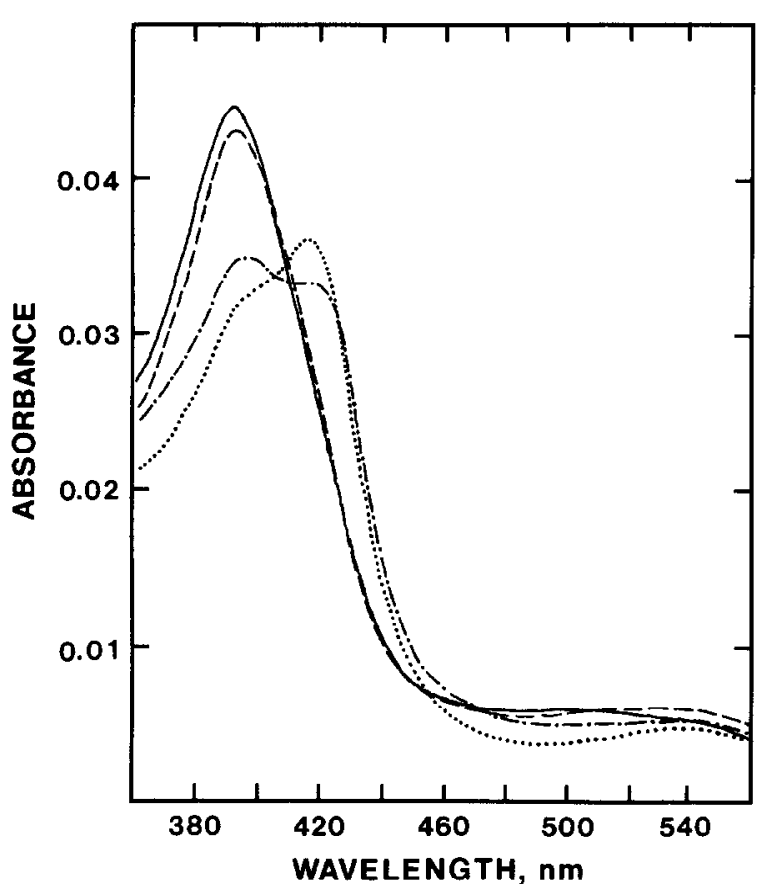

FIG. 4. Absolute spectra of purified 2E1 and 2E2 from acetone-treated adult rabbits. The concentrations of the cytochromes, based on heme analysis, were $0.45 \mathrm{nmol}$ per milliliter of $0.1 \mathrm{M}$ potassium phosphate buffer, $\mathrm{pH} 7.4$, containing varying amounts of glycerol. (-) $2 \mathrm{E1}$ with $0.3 \%$ glycerol; (--) $2 \mathrm{E} 1$ with $20 \%$ glycerol; ( $-\cdots)$ copurified $2 \mathrm{E} 1$ and $2 \mathrm{E} 2$ in $1.6 \%$ glycerol; $(\cdots)$ copurified $2 \mathrm{E} 1$ and $2 \mathrm{E} 2$ in $20 \%$ glycerol.

The first $30 \mathrm{NH}_{2}$-terminal residues of the mixed $2 \mathrm{E} 1$ and 2E2 preparation from acetone-treated adult rabbits were also determined and found to agree with those of $2 \mathrm{E} 2$ except at cycle 14, where a mixture of Ala and Val was found at a molar ratio of approximately $1: 6$. Cleavage of the three residues at the $\mathrm{NH}_{2}$-terminus was also observed, but the fraction of the degraded protein was only about $6 \%$. It is not clear if the apparently lower extent of degradation results from in vivo protection of the $2 \mathrm{E}$ proteins by acetone, or from an inherent resistance of $2 \mathrm{E} 1$ to proteolysis. In this connection, it is known that heterologously expressed $2 \mathrm{E} 1$ has greater stability than $2 \mathrm{E} 2$ during detergent solubilization and fractionation (13).

Immunochemical analysis. Immunoblot analysis (Fig. 2) of neonatal microsomes and purified $2 \mathrm{E} 2$ was performed with three different antibodies to $2 \mathrm{E} 1$ : a polyclonal, inhibitory antibody to rabbit 2E1; a monoclonal, noninhibitory antibody (1H.11) to rabbit $2 \mathrm{E} 1$; and a monoclonal antibody (1-98-1) to rat $2 \mathrm{E} 1$. All three antibodies recognized purified $2 \mathrm{E} 2$ as well as a single band with the same mobility in hepatic microsomes, thus establishing that purified $2 \mathrm{E} 2$ is immunochemically related to $2 \mathrm{E} 1$. In other experiments, the level of $2 \mathrm{E} 2$ in liver microsomes of 2-week-old rabbits was found to be approximately 25 to $30 \%$ of the total microsomal P450 based on immunoquantitation with purified $2 \mathrm{E} 2$ as a standard and the assumption that the level of $2 \mathrm{E} 1$ is negligible at this age.
In contrast, the combined level of $2 \mathrm{E} 1$ and $2 \mathrm{E} 2$ in adult rabbit liver is about $5 \%$ of the total microsomal P450 (39). Bonfils et al. (15) reported that the combined level of $1 \mathrm{~A} 1,1 \mathrm{~A} 2,2 \mathrm{~B} 4,2 \mathrm{C} 3$, and $3 \mathrm{~A} 6$ accounts for about $40 \%$ of total P450 at 2 weeks of age. Thus, $2 \mathrm{E} 2$ appears to be the principal hepatic $\mathrm{P} 450$ at this age.

Spectral properties. As is shown in Fig. 3, glycerol, which is present in the storage buffer to stabilize P450, significantly alters the spectral properties of $2 \mathrm{E} 2$. Ferric $2 \mathrm{E} 2$ is predominantly low-spin in the presence of $20 \%$ glycerol, with an absorption coefficient of $108 \mathrm{mM}^{-1} \mathrm{~cm}^{-1}$ for the absorbance maximum at $414 \mathrm{~nm}$, but the cytochrome is in a mixed high- and low-spin state with absorbance maxima at 393 and $417 \mathrm{~nm}$ when the glycerol concentration is $0.13 \%$. It is not known if $2 \mathrm{E} 2$ is completely high-spin in the absence of glycerol since removal of glycerol by dialysis results in formation of $\mathrm{P} 420$, which has maximal absorbance at 412 to $413 \mathrm{~nm}$ in the ferric state (data not shown). The absolute spectrum of dithionite-reduced $2 \mathrm{E} 2$ exhibits an absorption maximum at $415 \mathrm{~nm}$ with an absorption coefficient of $89 \mathrm{~mm}^{-1} \mathrm{~cm}^{-1}$ in the presence of $20 \%$ glycerol but displays an absorbance maximum at $420 \mathrm{~nm}$ with an absorption coefficient of 81 $\mathrm{mM}^{-1} \mathrm{~cm}^{-1}$ in the presence of $0.13 \%$ glycerol. A small

TABLE II

Monooxygenase Activities of $2 \mathrm{E} 1$ and $2 \mathrm{E} 2^{\circ}$

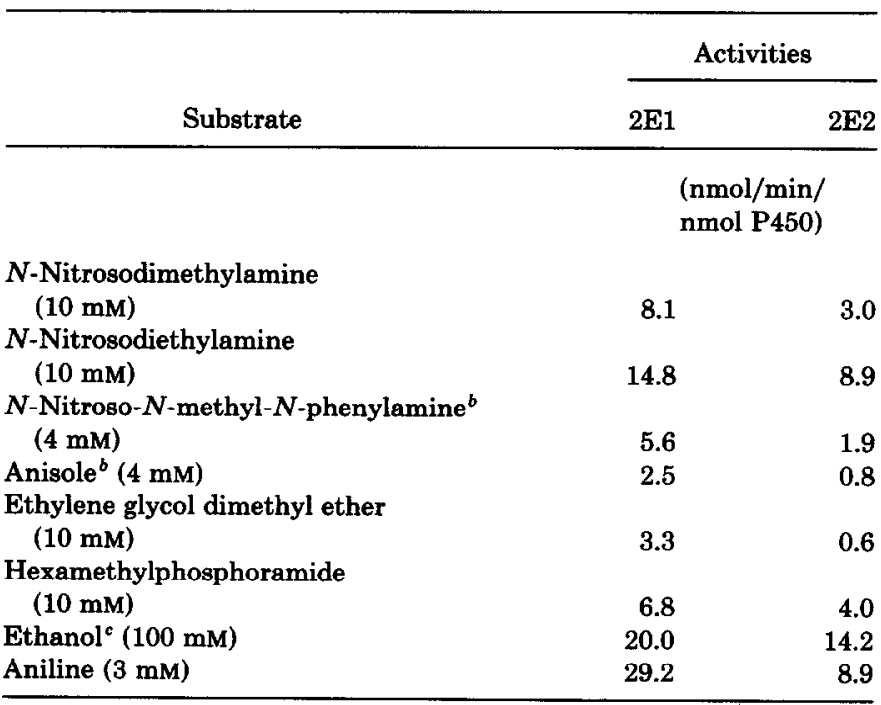

${ }^{a}$ Unless otherwise indicated, the reaction mixtures contained $100 \mathrm{mM}$ potassium phosphate buffer, $\mathrm{pH} 6.8$, a reconstituted system with 0.05 $\mu \mathrm{M}$ P450, $0.15 \mu \mathrm{M}$ NADPH-cytochrome P450 reductase, and $15 \mu \mathrm{g} / \mathrm{ml}$ phospholipid, and $1 \mathrm{mM} \mathrm{NADPH}$. All reactions were carried out at $37^{\circ} \mathrm{C}$. The concentrations of glycerol present were $15 \mathrm{mM}$ with $N$-nitrosodimethylamine, $N$-nitroso- $N$-methyl- $N$-phenylamine, anisole, ethylene glycol dimethyl ether, or hexamethylphosphoramide, $35 \mathrm{mM}$ with $N$ nitrosodiethylamine or aniline, and $70 \mathrm{mM}$ with ethanol. The reaction product measured was $p$-aminophenol with aniline, acetaldehyde with $N$-nitrosodiethylamine or ethanol, or formaldehyde with the other substrates.

${ }^{b}$ Substrate was added in $4 \mu \mathrm{l}$ of ethanol to a $1-\mathrm{ml}$ final volume.

'The incubation mixture contained $50 \mathrm{mM}$ phosphate buffer, $\mathrm{pH}$ 7.4. 
TABLE III

Effect of $b_{5}$ on the Oxygenase Activities of $2 \mathrm{E} 1$ and $2 \mathrm{E} 2^{a}$

\begin{tabular}{lccr}
\hline & & \multicolumn{2}{c}{ Activities } \\
\cline { 3 - 4 } Substrate & $\begin{array}{c}\text { Molar ratio, } \\
\mathbf{b}_{5} / \text { P450 }\end{array}$ & $2 \mathrm{E} 1$ & $2 \mathrm{E} 2$ \\
\hline & & \multicolumn{2}{c}{ (nmol/min/ } \\
& & \multicolumn{2}{c}{ nmol P450) } \\
N-Nitrosodimethylamine & 0 & 5.0 & 2.8 \\
(2.1 mM) & 4 & 6.6 & 7.0 \\
N-Nitrosodiethylamine & 0 & 9.3 & 2.9 \\
(2.0 mM) & 8 & 8.7 & 6.2 \\
& 0 & 26.5 & 10.9 \\
Butanol (15 mM) & 8 & 10.8 & 8.7 \\
& 0 & 8.3 & 5.0 \\
p-Nitrophenol (0.1 mM) & 4 & 30.8 & 21.9 \\
\hline
\end{tabular}

${ }^{a}$ Reaction mixtures contained $50 \mathrm{mM}$ phosphate buffer, $\mathrm{pH}$ 7.4, except for $p$-nitrophenol hydroxylation, which was at $\mathrm{pH} 6.8$. The concentrations of glycerol present are $15 \mathrm{mM}$ with $N$-nitrosodiethylamine or $p$ nitrophenol, $35 \mathrm{mM}$ with $N$-nitrosodimethylamine, and $70 \mathrm{mM}$ with butanol. Other conditions were as in Table II.

shoulder was found at about $448 \mathrm{~nm}$ in the presence of $20 \%$ glycerol, but not at the lower glycerol concentration, and was more prominent at glycerol concentrations higher than $20 \%$ (not shown). The glycerol-induced absorbance change at $448 \mathrm{~nm}$ was also found with $2 \mathrm{~F} 1$, although to a smaller extent. In other experiments with either $2 \mathrm{E} 1$ or 2E2, pronounced shoulders were observed at 446 to 448 $\mathrm{nm}$ in the presence of other ligands such as 4-MP or dimethyl sulfoxide. The absolute spectrum of reduced, $\mathrm{CO}$ complexed $2 \mathrm{E} 2$ shows a small amount of P420 and an absorption maximum at $452 \mathrm{~nm}$ with an absorption coefficient of $124 \mathrm{~mm}^{-1} \mathrm{~cm}^{-1}$ in the presence of $20 \%$ glycerol and $101 \mathrm{mM}^{-1} \mathrm{~cm}^{-1}$ in the presence of $0.13 \%$ glycerol. The reduced carbonyl difference spectrum of $2 \mathrm{E} 2$ (not shown) exhibits a maximum at $452 \mathrm{~nm}$ with an absorption coefficient of $84 \mathrm{~mm}^{-1} \mathrm{~cm}^{-1}$ in the presence of $20 \%$ glycerol and $71 \mathrm{mM}^{-1} \mathrm{~cm}^{-1}$ in the presence of $0.13 \%$ glycerol. Thus, glycerol affects the spin state and the absorption coefficients of ferric, ferrous, and $\mathrm{CO}$-complexed ferrous $2 \mathrm{E} 2$ in a concentration-dependent manner. In the report by Bonfils et al. (15), the partially purified P450 2y (with a specific content of $8 \mathrm{nmol} / \mathrm{mg}$ of protein) had an absorbance maximum at $418 \mathrm{~nm}$ in the oxidized state, $422 \mathrm{~nm}$ in the reduced state, and $452 \mathrm{~nm}$ in the CO-complexed state. However, it was not indicated whether glycerol was present.

The absolute spectra of purified $2 \mathrm{E} 1$ and of the mixture of $2 \mathrm{E} 1$ and $2 \mathrm{E} 2$ from acetone-treated adult rabbits are shown in Fig. 4. Notably, the oxidized spectrum of $2 \mathrm{E} 1$ does not show a significant spin shift (high- to low-spin) when recorded in the presence of $0.3 \%$ or $20 \%$ glycerol, although a small decrease in the absorbance at $393 \mathrm{~nm}$ is observed with $20 \%$ glycerol. This is in contrast to the spectrum of the mixed $2 \mathrm{E} 1 / 2 \mathrm{E} 2$ preparation, which shows a high- to low-spin shift when the glycerol concentration is increased from 1.6 to $20 \%$.

Catalytic properties. The substrate specificity of purified $2 \mathrm{E} 2$ was studied in the reconstituted enzyme system containing NADPH, NADPH-cytochrome P450 reductase, and phophatidylcholine. As shown in Table II, 2E2 is active toward all of the substrates tested, although less so than is $2 \mathrm{E} 1$ under identical conditions. The ratio of activities for $2 \mathrm{E} 1$ to $2 \mathrm{E} 2$ varies from 1.4 for ethanol to 5.5 for ethylene glycol dimethyl ether. Glycerol, which is known to be a weak inhibitor $(40,41)$ of rat $2 \mathrm{E} 1$, was present in the incubation mixtures as a stabilizing agent for the enzymes, as indicated in the legend to the table. Therefore, the observed activity differences may be due, at least in part, to differential inhibition by glycerol. The results presented clearly show that $2 \mathrm{E} 2$ catalyzes the reactions already identified for $2 \mathrm{E} 1$, but further studies will be required to establish the detailed kinetic differences between the two isozymes.

The effect of $b_{5}$ on the activities of $2 \mathrm{E} 2$ was examined with four different substrates, with the results shown in Table III. Differential effects of $b_{5}$ on the activities of $2 E 1$ and $2 E 2$ were found. For instance, $b_{5}$ did not have a significant effect on the 2E1-catalyzed dealkylation of $N$ nitrosodiethylamine or $N$-nitrosodimethylamine at the substrate concentrations used, but increased the activity of $2 \mathrm{E} 2$ more than twofold with either substrate. Conversely, $b_{5}$ inhibited $2 \mathrm{E} 1$ activity with butanol by $60 \%$ but 2 E2 activity by only $20 \%$. Nevertheless, the extent of stimulation of the $p$-nitrophenol hydroxylation activity of $2 \mathrm{E} 1$ and $2 \mathrm{E} 2$ by $b_{5}$ was similar. Interestingly, the ratio of activities of $2 \mathrm{E} 1$ to $2 \mathrm{~F} 2$ was reduced to nearly unity $(0.9-1.4)$ in the presence of $b_{5}$ for all four substrates. In experiments not presented, both $2 \mathrm{E} 1$ - and $2 \mathrm{E} 2$-catalyzed butanol oxidation were inhibited by a polyclonal anti$2 \mathrm{E} 1$ antibody by about $90 \%$ at a ratio of $10 \mathrm{mg}$ of $\mathrm{IgG} /$ nmol of P450. Cytochrome 2E1 was consistently more active than $2 \mathrm{E} 2$ with butanol as a substrate, whether the reaction was conducted at $\mathrm{pH} 6.4$ or 7.7 , or at substrate

TABLE IV

Stoichiometry of 2E-Catalyzed NADPH Oxidase Reaction ${ }^{a}$

\begin{tabular}{cccccc}
\hline Enzyme & $\begin{array}{c}\mathrm{NADPH} \\
\text { oxidized } \\
\text { (a) }\end{array}$ & $\begin{array}{c}\mathrm{O}_{2} \\
\text { consumed } \\
\text { (b) }\end{array}$ & $\begin{array}{c}\mathrm{H}_{2} \mathrm{O}_{2} \\
\text { formed } \\
\text { (c) }\end{array}$ & $\begin{array}{c}\text { Molar ratio, } \\
\mathrm{NADPH} / \\
\mathrm{O}_{2} / \mathrm{H}_{2} \mathrm{O}_{2}\end{array}$ & $\begin{array}{l}\text { (a) - (c) } \\
\text { (b) (c) }\end{array}$ \\
\hline \multicolumn{7}{c}{ (nmol/ml reaction mixture) } \\
$2 \mathrm{E} 1$ & $141 \pm 0$ & $89 \pm 8$ & $25 \pm 1$ & $1.58: 1.0: 0.28$ & 1.8 \\
$2 \mathrm{E} 2$ & $138 \pm 4$ & $89 \pm 4$ & $16 \pm 1$ & $1.55: 1.0: 0.18$ & 1.7 \\
\hline
\end{tabular}

${ }^{a}$ Duplicate determinations were made for each isozyme. The experimental values are given as the mean and standard deviation. In other experiments, the ratio of $\mathrm{O}_{2}$ consumed to $\mathrm{H}_{2} \mathrm{O}_{2}$ formed during turnover of glucose oxidase with $\beta-\mathrm{D}(+)$-glucose was 0.95 . The concentration of glycerol in the reaction mixtures containing $2 \mathrm{E} 1$ and $2 \mathrm{E} 2$ was 67 and $207 \mathrm{mM}$, respectively. 
concentrations ranging from 0.6 to $15 \mathrm{mM}$ without $b_{5}$ but in the presence of $70 \mathrm{mM}$ glycerol.

NADPH oxidase activity in the absence of substrate. Previous investigation of the stoichiometry of the P450catalyzed NADPH oxidase reaction in the absence of substrate indicated that $2 \mathrm{E} 1$ utilizes a small fraction of NADPH-derived reducing equivalents for $\mathrm{H}_{2} \mathrm{O}_{2}$ formation, with most of the NADPH presumably being oxidized in the four-electron reduction of molecular oxygen to water (9). In the present study, stoichiometric determinations were conducted with both $2 \mathrm{E} 1$ and $2 \mathrm{E} 2$ in a reconstituted system under endpoint conditions as previously described (9). After addition of a limiting amount of NADPH, $\mathrm{O}_{2}$ consumption was followed to completion of the reaction, which took 13 and 26 min with $2 \mathrm{E} 1$ and $2 \mathrm{E} 2$, respectively. While the rate of oxygen consumption for $2 \mathrm{E} 2$ is lower than that seen for $2 \mathrm{E} 1,2 \mathrm{E} 2$ is nevertheless more active than the other $\mathrm{P} 450$ isozymes previously examined. The extent of $\mathrm{O}_{2}$ consumption was the same for both isozymes as illustrated in Table IV, but the amount of $\mathrm{H}_{2} \mathrm{O}_{2}$ formed with $2 \mathrm{E} 2$ was about two-thirds of that with $2 \mathrm{E} 1$. The two-electron oxidase activity of $2 \mathrm{E} 1$ or $2 \mathrm{E} 2$ accounted for less than one-fifth of the NADPH oxidized. When the amounts of $\mathrm{NADPH}$ oxidized and $\mathrm{O}_{2}$ consumed were taken into account for $\mathrm{H}_{2} \mathrm{O}_{2}$ formation, it was apparent that, in addition, nearly $2 \mathrm{~mol}$ of NADPH were oxidized for each mole of $\mathrm{O}_{2}$ consumed. Taken together, the data indicate that the rapid consumption of $\mathrm{O}_{2}$ hy the $2 \mathrm{E}$ isozymes in the absence of a hydroxylatable substrate is mostly associated with $\mathrm{H}_{2} \mathrm{O}$ formation.

\section{ACKNOWLEDGMENT}

We are grateful to Carole J. Davis for excellent technical assistance.

\section{REFERENCES}

1. Koop, D. R., and Coon, M. J. (1986) Alcohol. Clin. Exp. Res. 10, 44S-49S.

2. Nebert, D. W., Nelson, D. R., Coon, M. J., Estabrook, R. W., Feyereisen, R., Fujii-Kuriyama, Y., Gonzalez, F. J., Guengerich, F. P. Gunsalus, I. C., Johnson, E. F., Loper, J. C., Sato, R., Waterman, M. R., and Waxman, D. J. (1991) DNA Cell Biol. 10, 1-14.

3. Khani, S. C., Porter, T. D., Fujita, V. S., and Coon, M. J. (1988) J. Biol. Chem. 263, 7170-7175.

4. Koop, D. R., Morgan, E. T., Tarr, G. E., and Coon, M. J. (1982) J. Biol. Chem. 257, 8472-8480.

5. Morgan, E. T., Koop, D. R., and Coon, M. J. (1982) J. Biol. Chem. 257, 13,951-13,957.

6. Yang, C. S., Yoo, J. S. H., Ishizaki, H., and Hong, .J. (1990) Drug Metab. Rev. 22, 147-159.

7. Vaz, A. D. N., Roberts, E. S., and Coon, M. J. (1990) Proc. Natl. Acad. Sci. USA 87, 5499-5503.

8. Koop, D. R., and Casazza, J. P. (1985) J. Biol. Chem. 260, 13,60713,612 .

9. Gorsky, L. D., Koop, D. R., and Coon, M. J. (1984) J. Biol. Chem. 259, 6812-6817.

10. Ekstrom, G., and Ingelman-Sundberg, M. (1989) Biochem. Pharmacol. 38, 1313-1319.
11. Tindberg, N., and Ingelman-Sundberg, M. (1989) Biochemistry 28, 4499-4504.

12. Porter, T. D., Khani, S. C., and Conn, M. J. (1989) Mol. Pharmacol. 36, 61-65.

13. Pernecky, S. J., Porter, T. D., and Coon, M. J. (1990) Biochem. Biophys. Res. Commun. 172, 1331-1337.

14. Koop, D. R. (1990) Chem. Res. Toxicol. 3, 377-383.

15. Bonfils, C., Combalbert, J., Pineau, T., Angevin, J., Larroque, C., Derancourt, J., Capony, J.-P., and Maurel; P. (1990) Eur. J. Biochem. 188, 187-194.

16. Peng, H.-M., Porter, T. D., Ding, X., and Coon, M. J. (1991) Mol. Pharmacol. 40, 58-62.

17. Coon, M. J., van der Hoeven, T. A., Dahl, S. B., and Haugen, D. A. (1978) in Methods in Enzymology (Fleischer, S., and Packer, L., Eds.), Vol. 52, pp. 109-117, Academic Press, San Diego.

18. Koop, D. R., and Coon, M. J. (1984) Mol. Pharmacol. 25, 494-501.

19. Thurman, R. G., Ley, H. G., and Scholz, R. (1972) Eur. J. Biochem. 25, 420-430.

20. Robinson, J., and Cooper, J. M. (1970) Anal. Biochem. 33, 390399.

21. Bernt, E., and Bergemeyer, H. U. (1974) in Methods of Enzymatic Analysis (Bergemeyer, H. U., Ed.), Vol. 4, pp. 2246-2248, Academic Press, New York.

22. Gorsky, L. D., and Coon, M. J. (1986) Drug Metab. Dispos. 14, 8996.

23. Koop, D. R. (1986) Mol. Pharmacol. 29, 399-404.

24. Nash, T. (1953) Biochem. J. 55, 416-421.

25. Koop, D. R., Nordblom, G. D., and Coon, M. J. (1984) Arch. Biochem. Biophys. 235, 228-238.

26. Ding, X., and Coon, M. J. (1988) Drug Metab. Dispos. 16, 265-269.

27. Mieyal, J. J., Ackerman, R. S., Blumer, J. L., and Freeman, L. S. (1976) J. Biol. Chem. 254, 3436-3441.

28. Omura, T., and Sato, R. (1964) J. Biol. Chem. 239, 2370-2378.

29. Antonini, E., and Brunori, M. (1971) in Hemoglobins and Myoglohins in Their Reactions with Ligands (Neuberger, A., and Tatum, E. L., Eds.) North-Holland, London.

30. Hewick, R. M., Hunkapillar, M. W., Hood, L. E., and Dreyer, W. J. (1981) J. Biol. Chem. 256, 7990-7997.

31. Ding, X., Koop, D. R., Crump, B. L., and Coon, M. J. (1986) Mol. Pharmacol. 30, 370-378.

32. Lowry, O. H., Rosebrough, N. J., Farr, A. L., and Randall, R. J. (1951) J. Biol. Chem. 193, 265-275.

33. Haugen, D. A., and Coon, M. J. (1976) J. Biol. Chem. 251, 79297939.

34. Strittmatter, P., Fleming, P., Connors, M., and Corcoran, D. (1978) in Methods in Enzymology (Fleischer, S., and Packer, L., Eds.), Vol. 52, pp. 97-101, Academic Press, San Diego.

35. French, J. S., and Coon, M. J. (1979) Arch. Biochem. Biophys. 195, 565-577.

36. Park, S. S., Ko, I.-Y., Patten, C., Yang, C. S., and Gelboin, H. V. (1986) Biochem. Pharmacol. 35, 2855-2858.

37. Ding, X., and Coon, M. J. (1988) Biochemistry 27, 8330-8337.

38. Larson, J. R., Porter, T. D., and Coon, M. J. (1991) J. Biol. Chem. 266, 7321-7324.

39. Koop, D. R., Crump, B. L., Nordblom, G. D., and Coon, M. J. (1985) Proc. Natl. Acad. Sci. USA 82, 4065-4069.

40. Clejan, L. A., and Cederbaum, A. I. (1990) Biochem. Biophys. Acta 1034, 233-237.

41. Yoo, J. S. H., Cheung, R. J., Patten, C., Wade, D., and Yang, C. S. (1987) Cancer Res. 47, 3378-3383. 